\title{
The link between landscape pattern and vegetation naturalness on a regional scale
}

\author{
P. Szilassi ${ }^{\mathrm{a}, *}$, T. Bata ${ }^{\mathrm{a}}$, Sz. Szabób ${ }^{\mathrm{b}}$, B. Czúcz ${ }^{\mathrm{c}}$, Zs. Molnár $^{\mathrm{c}}$, G. Mezősi ${ }^{\mathrm{a}}$ \\ a Department of Physical Geography and Geoinformatics, University of Szeged, Egyetem u. 2-6, H-6722 Szeged, Hungary \\ b Department of Physical Geography and Geoinformation Systems, University of Debrecen, Egyetemtée 1. H-4032, Hungary \\ ${ }^{\mathrm{c}}$ Institute of Ecology and Botany, Centre for Ecological Research, Hungarian Academy of Sciences, Alkotmány u. 2-4, H-2163, Vácrátót, Hungary
}

\section{A R T I C L E I N F O}

\section{Keywords:}

Landscape metrics

CORINE

Scale sensitivity

Landscape pattern

Vegetation based natural capital index

Hemeroby

\begin{abstract}
A B S T R A C T
The land use and land cover pattern of landscapes are key elements of basic landscape structure; accordingly, this pattern has an important role in landscape management, nature conservation and preservation. In Hungary, the naturalness of the vegetation was surveyed between 2003 and 2006, and the vegetation-based Natural Capital Index (NCI) was calculated for almost the entire area of the country. This field-based database gave us the unique opportunity to analyse the statistical connection between the naturalness of the vegetation and the landscape (land cover) pattern on a regional scale. In our study, we analysed the efficiency of the regional-level CORINE Land Cover (CLC) database for the estimation of the naturalness of the vegetation. This connection was analysed at the country scale using every (2272) Flora Mapping Unit (FMU), or $5.5 \times 6.5 \mathrm{~km}$ quadrate, of Hungary. We calculated the shape-, edge- and size-related landscape indices for all FMUs on a landscape level (including all CLC patches) and a class level (the land cover polygons were classified according to their land cover characteristics and their level of hemeroby). We determined the Spearman's correlations to reveal the statistical connections between the landscape metric parameters and the NCI values. All of the investigated areaweighted landscape indices: Main Patch Size, (MPS), Main Fractal Dimension Index, (MFDI), Total Edge (TE), Main Shape Index (MSI) and Number of Shape Characteristic Points (NSCP) on the landscape level showed a significant statistical connection with the NCI, but the sign of its correlation with the NCI contrasted with the findings from previous studies on a larger scale. Our study shows that scale has a strong impact on the sign of the correlation between the naturalness of the vegetation and the landscape structure. On a class level, particularly the shape-related landscape indices of the "Forest and semi-natural areas" showed statistically significant correlations with the NCI. The correlation strongly depended on the method of classification of the CLC polygons. Furthermore, the spatial pattern of the land-cover-type-based CLC polygon categories showed higher correlation values with the NCI than CLC polygon classes, which were categorized according to their hemeroby state. These results show that although the sign of the spatial pattern change in the main land cover classes is scale-dependent, they can be used to estimate the increase or decrease in the naturalness of the vegetation better than the spatial changes of the hemeroby-level-based landscape pattern. We can predict the change in the naturalness of vegetation based on the spatial changes in the land cover pattern.
\end{abstract}

\section{Introduction}

According to the pattern and process paradigm, the land cover pattern predicts the ecological processes occurring in a given landscape (Herzog et al., 2001; Renetzeder et al., 2010; Tasser et al., 2008; Winter and Fischer, 2010; Wrbka et al., 2004; Zebisch et al., 2004). Landscape metrics indicators, calculated on the basis of land cover patches, may be suitable for estimating vegetation biodiversity and the naturalness of the vegetation (Herzog et al., 2001; Moser et al., 2002; Schindler et al.,
2008; Szabó et al., 2012, 2013; Zebisch et al., 2004; Zhang et al., 2013). Studies using landscape metrics have usually applied land cover data; there are only a few examples in which the quality of the habitat patches was involved. Most of the examples involving quality (e.g., biodiversity, the naturalness of the vegetation) and landscape metric indicators were conducted on a local scale and described the relationship between the shape (complexity) of the patches and the naturalness of the vegetation. Landscape metrics calculated on the basis of patch geometries may be suitable to estimate the degree of naturalness of the

\footnotetext{
* Corresponding author.

E-mail addresses: toto@geo.u-szeged.hu (P. Szilassi), batateodora@gmail.com (T. Bata), szaboszilard.geo@gmail.com (S. Szabó), czucz.balint@okologia.mta.hu (B. Czúcz), molnar.zsolt@okologia.mta.hu (Z. Molnár), mezosi@geo.u-szeged.hu (G. Mezősi).
} 


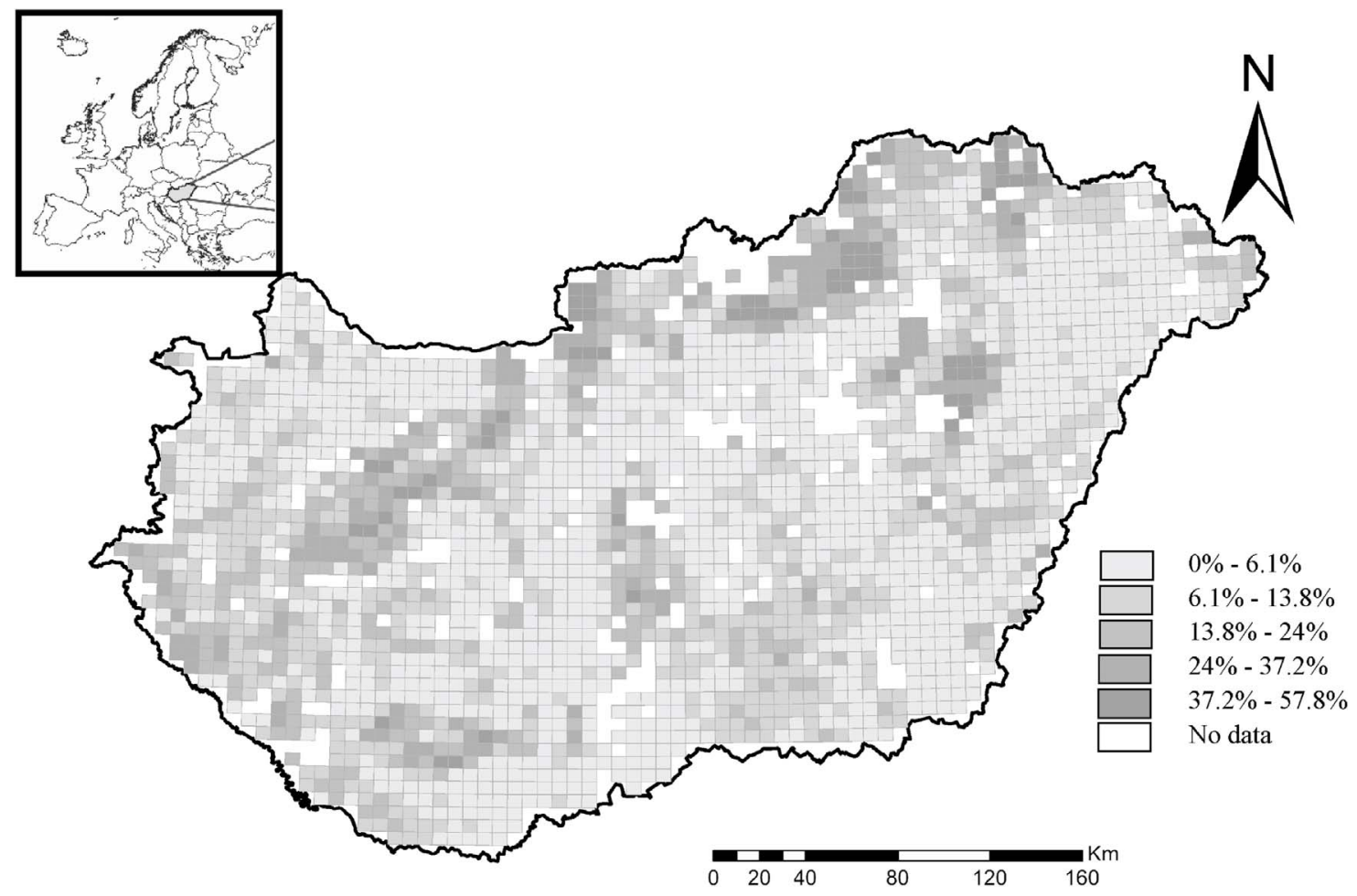

Fig. 1. NCI values of $5.5 \times 6.5 \mathrm{~km}$ FMU quadrate areas of Hungary based on botanical field survey between 2003 and 2006 .

Source: Czúcz et al., 2012.

vegetation (Lausch et al., 2015; Venturelli and Galli, 2006).The areaweighted means of pattern-level indicators (i.e., land cover indicators) in a sample quadrate were correlated with the botanical data collected during field work of the same quadrate (e.g., biodiversity, naturalness of vegetation; Gimona et al., 2009; Lausch and Herzog, 2002; Tischendorf, 2001; Uuemaa et al., 2013). Landscape metrics on a regional level were only weakly correlated with the diversity of vegetation (Gimona et al., 2009).

Vegetation may be characterized on the basis of the evaluation of field surveys (Alexander et al., 2016 Deák et al., 2015Deák et al., 2015). Different evaluation systems were developed, and in Hungary, social behaviour types (Borhidi, 1995) are often used to express the information about plant communities' stability, regeneration ability, naturalness and degree of disturbance. The method was adopted for national conditions from the system of Grime (1979). Furthermore, a new possibility is the application of the Natural Capital Index (NCI), which reflects the qualitative and quantitative (spatial) characteristics of the natural or semi-natural vegetation (Czúcz et al., 2012; ten Brink, 2000, 2007; ten Brink et al., 2002). Both indicators use vegetation data of field surveys, and the main difference is that SBT values are determined at the level of quadrats on a large scale, whereas the NCI is determined on a regional scale for almost the entire country. Hemeroby is used in ecological studies to express the degree of human influence on ecosystems and is associated with the human-induced disturbance in a landscape (Jalas, 1955). The calculation is based on land use, the share of neophytic and therophytic species, and soil characteristics (Sukopp, 1976) and may be used as the inverse of naturalness (Anderson, 1991; Jalas, 1955). The higher the degree of hemeroby, the more harmful the human influence and the more disturbed and transformed a landscape becomes (Machado, 2004).

Combining the indices of naturalness and landscape metrics can provide a possibility to accelerate surveys; i.e., if there is a strong statistical relationship between a landscape metric and a measure of vegetation naturalness, the latter's value can be predicted using the characteristics of habitat patches and their spatial pattern. Currently, most researchers prefer using landscape change tendencies as indicators for vegetation naturalness instead of using indicators requiring vegetation mapping (Bürgi and Russel, 2001; Frank et al., 2012; Frondoni et al., 2011; Kerényi and Szabó, 2007; OECD, 2001; Rüdisser et al., 2016; Walz, 2008, 2011; Walz and Syrbe, 2013; Zebisch et al., 2004). However, it is difficult to calculate the changes in naturalness on the basis of the changes in landscape patterns because the statistical relationship between landscape metrics indicators and naturalness is not linear (Blaschke, 2006; Tischendorf, 2001). Several authors emphasize that their class-level landscape pattern can be used more effectively in the estimation of naturalness than those landscape level analyses that were calculated on the basis of the total number of the patches (Lausch and Herzog, 2002; Renetzeder et al., 2010; Szabó et al., 2012, 2013; Tischendorf, 2001).

Regarding the limited accessibility of vegetation based landscape naturalness indicators on an appropriate scale, no research has been conducted to a country wide extent using data on a medium scale. In this study, we applied medium scale data of naturalness (Natural Capital Index) with landscape metrics calculated from the CLC 2006 database and revealed whether there was a deterministic relationship between the data based on field vegetation surveys and the landscape metrics derived from the spatial characteristics of habitat patches on a 1:100 000 scale. We investigated whether hemeroby- or land-coverbased categorization had a stronger correlation with the NCI. We also aimed to study the scale sensitivity of this connection. Furthermore, we intended to ascertain whether the relationship in our regional-level analyses had the same sign as previous, high resolution, large scale analyses and to reveal how landscape-pattern-change tendencies can be used as indicators to estimate the changes in the naturalness of the vegetation.

\section{Materials and methods}

\subsection{Case study area}

Hungary (Fig. 1.) is located in Central Europe (between $\mathrm{N}$ 45.48 - 48.35 and E $16.50-22.48$ ). Its total area is $93033 \mathrm{~km}^{2}$, it has 
Table 1

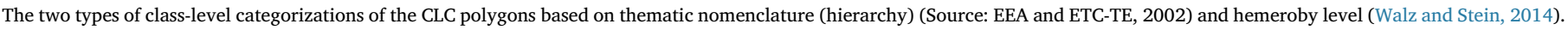

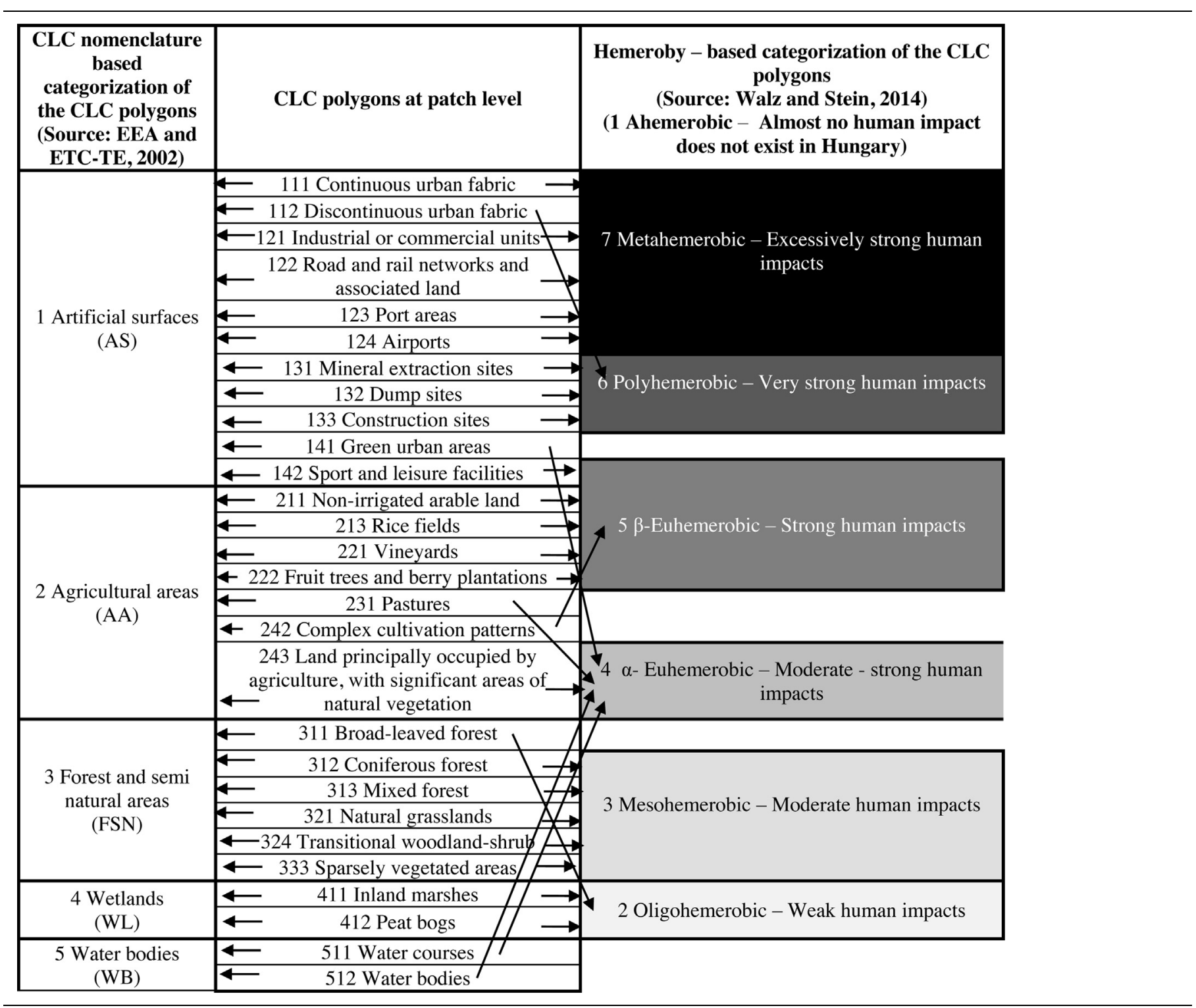

elevations ranging from $77 \mathrm{~m}$ to $1014 \mathrm{~m}$ a.s.l., and it is situated in the Carpathian Basin. The northern and western parts of the country are mountainous and hilly areas characterized by forests. The hills and mountains of the Carpathian Basin were characterized by oak and beech forests, parts of which were cleared for mining and agriculture (grape vine cultivation, arable land cultivation). In these areas, the species composition of forests is semi-natural or dominated by plantations of non-native species due to economy-based forest management.

The Great Hungarian Plain situated in the central and southern parts of the Carpathian Basin is filled with Quaternary alluvial sandy deposits and Pleistocene loess. Holocene wetland sediments and alluvial sediments can be found in this region (Lóczy, 2015 Mezósi, 2011). The soils of the Carpathian Basin have good quality (Chernozem) and are suitable for cultivation, or are salty and/or water-logged thus less suitable for cultivation. The Great Hungarian Plain was characterized by foreststeppes in the Holocene, but due to the intensive agricultural production, the area has been dominantly utilized as arable land since the last centuries (Csorba, 2005; Szilassi et al., 2006; Csorba and Szabó, 2009). While natural habitats often have complex shapes with convex and concave edges, agricultural lands tend to be characterized by sharp- lined edges (Lausch et al., 2015; Venturelli and Galli, 2006).

\subsection{Databases used}

\subsubsection{Natural capital index}

For characterizing the naturalness of Hungarian landscapes, we calculated the NCI, which represents the value of the naturalness of the vegetation and the proportion of the natural vegetation into rectangular landscape units ("quadrats") of $5.5 \times 6.5 \mathrm{~km}$ according to the grid system of the Central European Flora Mapping Units (FMUs) (Horváth et al., 2008). The vegetation-based NCI was defined as a product of the remaining ecosystem size (quantity) and its quality (Czúcz et al., 2008). The naturalness of each FMU quadrat was characterized using primary data from the Hungarian Vegetation Mapping (HVM) database.

Large-scale vegetation mapping comprising the entire area of Hungary was performed by almost 200 field surveyors between 2003 and 2006, resulting in the HVM database (Molnár et al., 2007 Horváth et al., 2008). Within this survey, 86 different types of natural and seminatural habitat types were distinguished, with a detailed habitat guide to assist the participants and to standardize the process. The 
identification of attribute levels was supported by a detailed protocol (Bölöni et al., 2008).

Raw values of naturalness of vegetation given at the level of field survey hexagons (35 ha) were spatially aggregated for each FMU quadrat using the NCI aggregation framework (Czúcz et al., 2008 Czúcz et al.q, 2012), resulting in an area-weighted mean of the NCI values characterizing the ecological status (closeness to an ideal "pristine" state) of the vegetation of each quadrat. Due to data gaps in the HVM database, only 2272 quadrates ( $80 \%$ of the total) were available to calculate the NCI values (Fig. 1).

\subsubsection{Land cover data}

The CORINE Land Cover database (CLC) is a land cover map prepared using a uniform methodology for the countries of the European Union (EEA and ETC-TE 2002, EEA 2006). Its scale is 1:100 000; the minimum mapping unit was 25 ha for habitat patches and at least $100 \mathrm{~m}$ width for linear landscape elements. Mapping is repeated every six years; thus, three states of land cover have been available since the year 2000. In the case of Hungary, more than 40000 polygons were delineated and classified into 5 main groups and 28 subgroups with at least $85 \%$ thematic accuracy (EEA, 2006).

We used the CLC 2000 and the CLC 2006 databases to determine the class level landscape metrics and to study the relationship between landscape metric and the naturalness of the vegetation (NCI). This period is more or less identical to the NCI map's vegetation survey (2003-2006; Molnár et al., 2007 Horváth et al., 2008). The CLC 2000 and the CLC 2012 databases were used for estimating the changes in the naturalness between 2000 and 2012 .

According to the CLC nomenclature, CLC polygons were categorized into five further categories based on their land cover type: 1 , artificial surfaces (AS); 2, agricultural areas (AA); 3, forests and semi-natural areas (FSN); 4, wetlands (WL); and 5, water bodies (WB). To prepare class-level analyses, we used two methods to group the CORINE land cover polygons: first, on the basis of the main land cover categories defined by the CORINE nomenclature (EEA and ETC-TE, 2002), and second, on the basis of their hemeroby level which expresses human impact (Frondoni et al., 2011; Walz and Stein, 2014) (Table 1).

Land cover types are usually divided into 7 hemeroby categories, and as there are no ahemerobic areas in the Carpathian Basin that would be totally free from human impact, we divided the 28 CLC polygons found in Hungary into 6 categories by modifying Walz and Stein, 2014 methodology (Table 1).

\section{Methods}

\subsection{Landscape metrics}

The CORINE databases (CLC 2000; CLC 2006) were applied to calculate the landscape metrics. Patch-level landscape indices were calculated for each land cover polygon with the V-LATE extension of the Arc GIS 10.1 software (Lang and Tiede, 2003).

In the course of our landscape metrics analyses, we calculated the following patch-level landscape metrics indicators: size, shape, and the length of the edges. These indicators are labelled as the indices of the diversity or naturalness of vegetation (Fu et al., 2006; Moser et al., 2002; Renezteder, 2010; Uuemaa et al., 2013; Walz, 2011; Table 2).

Based on the patch-level landscape indices, area-weighted values were calculated on class and landscape levels in every FMU quadrates. Landscape-level area-weighted mean indices of each CLC polygon were calculated for every FMU quadrate based on all land cover polygons (3 level in CLC 2000 and 2006) having their centroids inside the FMU quadrates.

The area-weighted mean (AWM) landscape metrics have also been calculated at the class level for the centroids of polygons which were found inside the FMU quadrates for each main CLC land cover categories and for hemeroby categories. AWM equals the sum, across all patches in the quadrate, of the corresponding patch metric value multiplied by the proportional abundance of the patch and divided by the sum of patch areas.

\subsection{Statistical analysis}

We revealed the statistical connections between landscape metrics (see Table 3) and the NCI for all FMU quadrates of Hungary on a landscape level (including all CLC polygons) and for the grouped CLC polygons (grouping by land cover and hemeroby level; class level) with IBM SPSS Statistics 22 software. The distribution of the variables was analysed with the Shapiro-Wilk test, but most variables did not follow the normal distribution; therefore, we applied the non-parametric Spearman rank correlation coefficient (Sokal and Rohlf, 1969).

To estimate the change in vegetation naturalness, we used those landscape metrics indicators calculated on the basis of the shape of the FSN polygons that showed significant Spearman's correlations with the NCI value at the 0.01 level and exhibited changes between 2000 and 2012.

We estimated the increase or decrease in vegetation naturalness on the basis of the change tendencies of the landscape indicators. Based on the CLC 2000 and the CLC 2012 maps, we specified those class-level landscape metrics indicators that exhibited a statistically significant relationship with the NCI at the 0.01 level of significance and then subtracted them from each other. The changes in landscape metrics indicators were taken into account only in quadrates where the change in the landscape metrics indicators was the same sign as their statistical relationship with the NCI. Although we could not estimate the extent of the changes with this method, we could identify, on a country scale, the FMU quadrates where the vegetation naturalness increased or decreased between 2000 and 2012.

The values (AWMPS) and the complexity (AWTE, AWMFRACT, and AWNSCP) calculated based on the CLC FSN polygons at the class level increased between 2000 and 2012; therefore, our estimate suggests that the value of the NCI also increased. Where each of the previously mentioned landscape metrics decreased, our estimate suggests that the naturalness of the vegetation and the NCI value representing naturalness also decreased. The signs of the two metrics indicators that did not change or changed with opposite signs were categorized into the "not estimable change" category. Quadrates having no FSN polygons were also placed in this category.

\section{Results}

\subsection{Correlation of vegetation-based naturalness with landscape metrics}

Landscape metrics derived from CLC 2000 and CLC 2006 had similar values, and the sign of their correlations with the NCI values was identical, as well (Table 3). Accordingly, the land cover did not change relevantly in the period of a field survey of vegetation naturalness.

The (landscape level) landscape metrics (size, shape, and edge length of the patches) calculated on the basis of the total number of the land cover polygons showed statistically significant correlations with the NCI values ( $\mathrm{p}<0.01$ ) in 2000 and 2006 . The correlations usually indicated a moderate level of relationship on a landscape level in class level AA. The FSN exhibited higher correlation coefficients with NCI in both 2000 and 2006. These two land cover categories are more suitable for describing the naturalness of the vegetation than the landscape-level shape characteristics of all land cover patches. However, we must emphasize that the signs of the Spearman's $\rho$ describing the statistical relationship between the landscape pattern and the NCI were contrary to each other depending on whether the AA or the FSN polygons were being examined.

Three out of the five main land cover CLC categories did not show a significant relationship with the NCI values per quadrate: AS, WL, WB. This may be attributed to the fact that these land cover types were 
Table 2

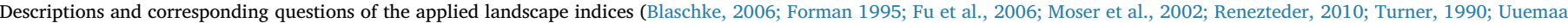
et al., 2013; Walz, 2011).

\begin{tabular}{|c|c|c|c|}
\hline Structural feature & Index & Name and description & Corresponding question \\
\hline Area & MPS & $\begin{array}{l}\text { Mean Patch Size is computed by dividing the area of the patches of the total landscape (or class) by } \\
\text { the number of patches }\end{array}$ & $\begin{array}{l}\text { What is the average patch size, and how are the } \\
\text { values distributed? }\end{array}$ \\
\hline Edges & $\mathrm{TE}$ & $\begin{array}{l}\text { Total Edge length in landscape involving patch type includes landscape boundary and background } \\
\text { segments involving patch type }\end{array}$ & $\begin{array}{l}\text { How much of a landscape or a patch type is } \\
\text { composed of edges? }\end{array}$ \\
\hline \multirow[t]{3}{*}{ Shape complexity } & SI & $\begin{array}{l}\text { Shape Index equals patch perimeter divided by the minimum perimeter possible for a maximally } \\
\text { compact patch (in a circle) of the corresponding patch area. }\end{array}$ & $\begin{array}{l}\text { How compact are the patches on average (in } \\
\text { comparison to a circle)? }\end{array}$ \\
\hline & FRACT & $\begin{array}{l}\text { Fractal Dimension Index equals } 2 \text { times the logarithm of patch perimeter }(\mathrm{m}) \text { divided by the } \\
\text { logarithm of patch area }\left(\mathrm{m}^{2}\right)\end{array}$ & $\begin{array}{l}\text { How complex or irregular is the form of the } \\
\text { patch? }\end{array}$ \\
\hline & NSCP & $\begin{array}{l}\text { The Number of Shape Characteristic Points is an index characterizing two-dimensional geometric } \\
\text { shapes by the minimum number of points necessary to describe their boundary. The NSCP } \\
\text { calculation algorithm only takes into account the vertices between vectors enclosing an angle } \\
\text { lower than } 160^{\circ} \text {. }\end{array}$ & $\begin{array}{l}\text { How complex or irregular is the form of the } \\
\text { patch? }\end{array}$ \\
\hline
\end{tabular}

Table 3

The Spearman's correlations between (NCI) and the landscape level metrics derived from land cover patches of CLC 2000 and CLC 2006.

\begin{tabular}{|c|c|c|c|c|c|c|c|c|c|c|c|c|c|}
\hline & & \multicolumn{2}{|l|}{ AWMPS } & \multicolumn{2}{|l|}{ AWTE } & \multicolumn{2}{|l|}{ AWMSI } & \multicolumn{2}{|l|}{$\begin{array}{l}\text { AW } \\
\text { MFRACT }\end{array}$} & \multicolumn{2}{|l|}{ AWNSCP } & \multicolumn{2}{|l|}{$\mathrm{N}$} \\
\hline & & $\begin{array}{l}\text { CLC } \\
2006\end{array}$ & $\begin{array}{l}\text { CLC } \\
2000\end{array}$ & CLC 2000 & CLC 2006 & CLC 2000 & CLC 2006 & CLC 2000 & CLC 2006 & CLC 2000 & CLC 2006 & CLC 2000 & CLC 2006 \\
\hline $\begin{array}{c}\text { landscape level } \\
\text { analyses }\end{array}$ & $\begin{array}{l}\text { all CLC } \\
\text { patches }\end{array}$ & $-0.496^{\mathrm{a}}$ & $-0.471^{\mathrm{a}}$ & $-0.477^{\mathrm{a}}$ & $-0.448^{\mathrm{a}}$ & $-0.466^{\mathrm{a}}$ & $-0.438^{\mathrm{a}}$ & $-0.409^{\mathrm{a}}$ & $-0.372^{\mathrm{a}}$ & $-0.372^{\mathrm{a}}$ & $-0.366^{\mathrm{a}}$ & 2272 & 2272 \\
\hline $\begin{array}{l}\text { CLC polygon } \\
\text { categories }\end{array}$ & $\begin{array}{l}1 \text { Artificial } \\
\text { surfaces (AS) }\end{array}$ & $-0.239^{\mathrm{a}}$ & $-0.223^{\mathrm{a}}$ & $-0.177^{\mathrm{a}}$ & $-0.168^{\mathrm{a}}$ & 0.029 & 0.022 & $0.154^{\mathrm{a}}$ & $0.139^{\mathrm{a}}$ & -0.042 & -0.033 & 2029 & 2054 \\
\hline $\begin{array}{l}\text { for the class } \\
\text { level }\end{array}$ & $\begin{array}{l}2 \text { Agricultural } \\
\text { areas (AA) }\end{array}$ & $-0.516^{a}$ & $-0.494^{\mathrm{a}}$ & $-0.503^{\mathrm{a}}$ & $-0.480^{a}$ & $-0.510^{\mathrm{a}}$ & $-0.492^{\mathrm{a}}$ & $-0.499^{\mathrm{a}}$ & $-0.483^{\mathrm{a}}$ & $-0.468^{\mathrm{a}}$ & $-0.461^{\mathrm{a}}$ & 2262 & 2263 \\
\hline $\begin{array}{l}\text { analyses of } \\
\text { the } \\
\text { landscape }\end{array}$ & $\begin{array}{l}3 \text { Forest and } \\
\text { semi natural } \\
\text { areas (FSN) }\end{array}$ & $0.624^{\mathrm{a}}$ & $0.613^{\mathrm{a}}$ & $0.612^{\mathrm{a}}$ & $0.603^{\mathrm{a}}$ & $0.564^{\mathrm{a}}$ & $0.559^{\mathrm{a}}$ & $0.451^{\mathrm{a}}$ & $0.456^{\mathrm{a}}$ & $0.599^{\mathrm{a}}$ & $0.597^{\mathrm{a}}$ & 2272 & 2123 \\
\hline \multirow[t]{2}{*}{ pattern } & $\begin{array}{l}4 \text { Wetlands } \\
\text { (WL) }\end{array}$ & 0.205 & $0.224^{\mathrm{a}}$ & 0.151 & 0.171 & 0.006 & 0.006 & -0.119 & $-0.128^{\mathrm{a}}$ & 0.126 & $0.148^{\mathrm{a}}$ & 773 & 613 \\
\hline & $\begin{array}{l}5 \text { Water } \\
\text { bodies (WB) }\end{array}$ & 0.069 & 0.079 & 0.032 & 0.042 & -0.027 & -0.022 & 0.079 & 0.074 & 0.045 & 0.045 & 806 & 836 \\
\hline
\end{tabular}

${ }^{\mathrm{a}}$ Correlation is significant at the 0.01 level.

characterized by only a few patches in most of the quadrates, so their area-weighted means represent the shapes of only a few patches per quadrate.

The correlation between the NCI and the hemeroby level of the land cover patches (determined on the class level) was not as strong as with $\mathrm{AA}$ and FSN, but the connections were significant $(\mathrm{p}<0.01)$. Spearman's $\rho$ values were less than 0.5 and had the largest values at the oligohemerobic level $(r=0.31-0.46 ; p<0.01)$ both in 2000 and 2006. In addition, NCI showed a strong correlation with the $\beta$-euhemerobic level (between -0.42 and -0.48 ) (Table 4).

The signs of the landscape metrics calculated on the basis of the hemeroby levels of the CLC categories and those of the NCI correlations are different from each other on each hemeroby level. While those hemeroby categories that are characterized by low human impact (oligohemerobic, mesohemerobic, $\alpha$-euhemerobic) were in positive correlation with the NCI values for all of the analysed landscape metrics indicators, those categories that were characterized by high human impact ( $\beta$-euhemerobic, polyhemerobic) changed to negative correlations.

\subsection{Qualitative estimation of the change in vegetation-based naturalness between 2000 and 2012}

According to our estimations, the naturalness of the vegetation increased in the central part of the Carpathian Basin (Fig. 2).

In this area, the cultivation of arable lands was abandoned in many cases, and abandonment induced an increase in semi-natural areas and forests. Contrary to this tendency, the human impact around Budapest (the capital city) and bigger cities grew between 2000 and 2012. According to our estimate based on the pattern changes of FSN polygons, the naturalness of the vegetation decreased in these areas.

\section{Discussion}

Although previous studies indicate that the CLC database cannot be used for estimating biodiversity (Gimona et al., 2009), we were able to show that the landscape metrics calculated on the basis of a regional scale CLC database had a statistically significant correlation with the vegetation-based naturalness (NCI) of the FMU quadrates.

Landscape level indicators describing the shape (i.e., patch geometry) of land cover patches were negatively correlated with NCI. The complex cultivated land patches having longer cultivated land edges indicated more agricultural land and a decrease in vegetation naturalness on a regional scale. The sign of the correlations between the NCI and the shape metrics differed depending on the metrics at the landscape or class level. Our results proved that class-level indicators showed a stronger statistical correlation with the NCI; therefore, they were more suitable for describing the hemeroby level than landscapelevel indicators (Lausch and Herzog, 2002; Tischendorf, 2001). Furthermore, the landscape metrics determined by the main land cover types were more suitable for estimating the direction of changes in vegetation naturalness than those categorized by hemeroby level, as reflected in the strength of the correlation. The landscape metrics of the FSN and the AA polygons showed significant correlations with the naturalness of the vegetation $(r=0.613$ and $r=-0.494)$. Due to the dominance of agricultural land use and its spatial pattern, the AA 
patches (most of which depict arable land) were considered the landscape matrix of Hungary, and the FSN polygons appeared as island-like patches in the matrix. Our results imply that a substantial part of Hungary is intensively utilized as an agricultural landscape because both the landscape metrics calculated on the basis of agricultural lands and the landscape-level landscape indices calculated on the basis of all land cover polygons are positively correlated with each other and the NCI to describe vegetation naturalness. The pattern of the agricultural land cover types is dominant in the landscape-level landscape pattern.

Accordingly, the pattern of the AA land use type must be taken into account, and it has a different sign than the pattern of the semi-natural (island-like) habitat patches located in the matrix when estimating the naturalness. Class-level metrics calculated on the basis of FSN polygons exhibit negative correlations with NCI values compared with the metrics of the AA areas. If the average size, edge length, and complexity of the agricultural land cover patches (matrix) increase while the FSN polygons in the matrix become more compact and their edge length decreases, the procedure indicates a decrease in vegetation naturalness.

Furthermore, there was greater vegetation based diversity when FSN patches had more complex shapes and larger sizes and when the AA patches were compact and had smaller parcels. However, we emphasize that it is true only when landscape metrics are calculated based on small, regional sale (ca. 1:100.000) land cover maps. A larger scale can change the sign of the correlation coefficients at both the AA class level and the cumulative landscape level.

Both Hungary and the EU member states are characterized by a tendency towards increasing compactness of patches given the landscape level metrics resulting from intensive land cultivation, where the parcels were large and had a regular shape (Moser et al., 2002). Our study revealed opposite signs of the correlations in case of the shape complexity indices (AWTE, AWMSI, AWMFRACT and AWNSCP), because this process can only be identified in such large scale land cover maps where the elemental patches are agricultural parcels (tesseras). The homogeneous patches of agricultural lands in the CLC database do not show this "fine" pattern, as the minimum patch size was 25 ha. Accordingly, several smaller agricultural parcels merged with their environs. This difference in scale may be the reason for statistical correlations with the opposite sign between the shape related landscape level metrics and indices of naturalness compared with the results of Moser et al., 2002 and Renetzeder et al., 2010. Previous studies (Gimona, 2009; Moser et al., 2002; Venturelli and Galli, 2006) showed that this relationship varies by landscape type; i.e., patch shape complexity does not presume an absolute relationship with natural value in every landscape. There is a significantly positive correlation between complex patch shape and biodiversity in the case of the natural or seminatural landscapes (Mander et al., 2005; Moser et al., 2002; Renetzeder et al., 2010). The relationship between the class level NSCP values calculated on the basis of FSN and the NCI values corresponded to these results; however, the landscape-level analysis did not correspond to them due to the predominance of agricultural land.

We identified a class-level land cover patch group, which is the most suitable for estimating the trends in vegetation-based naturalness on a regional scale. Class-level landscape metrics (AWMPS, AWTE, AWMFRACT, AWMSI and AWNSCP) calculated on the basis of the FSN polygons indicated statistically significant correlations at the 0.01 level $(r=0.451-0.624)$ with vegetation-based naturalness. These class-level indicators are the most suitable for estimating the changes in the naturalness of the vegetation.

FSN land cover patches that are characterized by a few bordering points and mainly linear, regular borderlines indicate significant human impact. They are characteristic of plantation-like forests having low naturalness and of grasslands surrounded by arable lands. In contrast, FSN patches having a complex shape with irregular edges indicate a higher level of naturalness (Moser et al., 2002). The greater extent of irregular FSN patch edges with complex shapes indicated higher NCI. AWTE, AWMSI, AWMFRACT and AWNSCP were appropriate tools for 


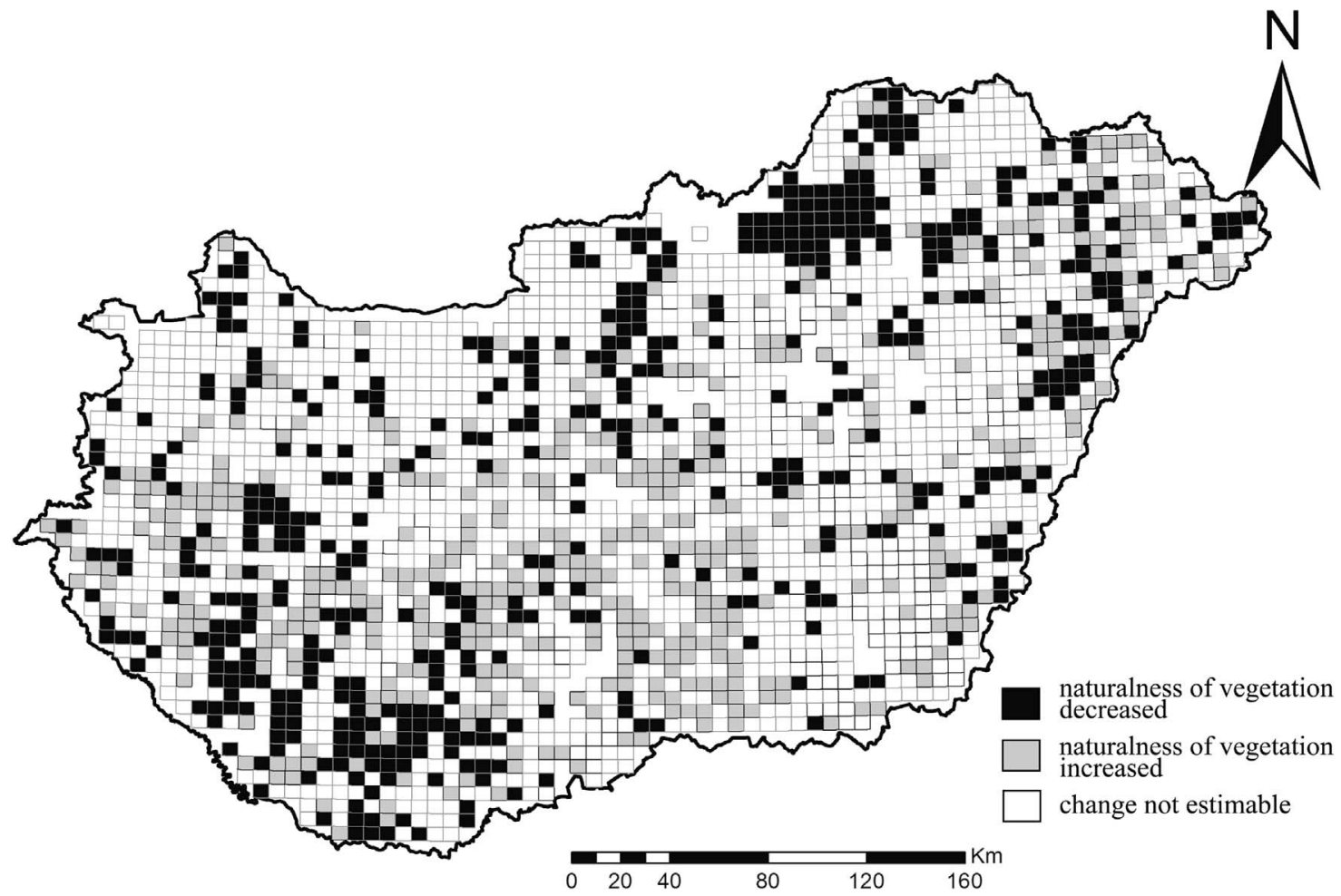

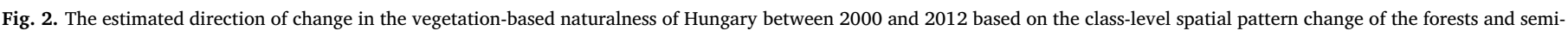
natural (FSN) areas based on CLC 2000 and CLC 2012 polygons.

describing the shape characteristics of the patches. This relationship is presumably not linear (Tischendorf, 2001); therefore, only the direction of change, i.e., the increasing or decreasing naturalness of the vegetation, can be used to estimate the changes in the FSN polygons' naturalness.

International literature indicates that increasing human impact results in a tendency of the average size of landscape level land cover polygons (AWEMPS) to grow in local scale (Moser et al., 2002). Our analysis on the landscape-level with the same index corroborated this result, but when we analysed FSN polygons on the class level, the tendency was the opposite, which means that the increasing size of semi-natural patches indicated the increasing naturalness of a certain area.

\section{Conclusions}

We conducted a spatial analysis of landscape metrics derived from regional scale land cover maps (CLC 2000; CLC 2006) to reveal whether there is a significant relationship with an indicator of vegetation naturalness (i.e. Natural Capital Index).

The regional scale map of vegetation naturalness (NCI, based on the national vegetation field survey) showed significant statistical correlation with the landscape pattern acquired from the regional scale CLC database. We proved that shape- and size-related landscape indices could be appropriate for describing the naturalness of vegetation and for predicting the possible changes of vegetation-based naturalness on regional scale.

We demonstrated that the class level indices are more suitable for describing the naturalness of vegetation than the landscape level indices. The hemeroby-based classification of CLC polygons showed weaker correlations with the vegetation-based naturalness than the land-cover-based (main CLC classes) categorisation. The correlations we obtained now had opposite signs when compared with the previous studies concerning the statistical analyses of the connection between class-level, shape-related indices of agricultural areas and vegetation- based naturalness. This result emphasises the scale sensitivity of landscape pattern analyses. These correlations reflect the direction of changes in vegetation-based naturalness in regional scale and are appropriate to estimate future trends. We estimated the directions of change in vegetation-based naturalness in regional scale.

\section{References}

Alexander, C., Deák, B., Heilmeier, H., 2016. Micro-topography driven vegetation patterns in open mosaic landscapes. Ecol. Indic. 60, 906-920. http://dx.doi.org/10. 1016/j.ecolind.2015.08.030.

Anderson, J.E., 1991. A conceptual framework for evaluating and quantifying naturalness. Conserv. Biol. 5 (3), 347-352. http://dx.doi.org/10.1111/j.1523-1739.1991. tb00148.x.

Bölöni, J., Molnár, Zs., Horváth, F., Illyés, E., 2008. Naturalness-based habitat quality of the Hungarian (semi-)natural habitats. Acta Bot. Hung. 50 (Suppl. 7), 149-160. http://dx.doi.org/10.1556/ABot.50.2008.

Bürgi, M., Russel, E.W.B., 2001. Integrative methods to study landscape changes. Land Use Policy. 18, 9-16. http://dx.doi.org/10.1016/S0264-8377(00)00041-7.

Blaschke, T., 2006. The role of the spatial dimension within the framework of sustainable landscapes and natural capital. Landsc. Urban Plan. 75 (3-4), 198-226. http://dx. doi.org/10.1016/j.landurbplan.2005.02.013.

Borhidi, A., 1995. Social behaviour types, the naturalness and relative ecological indicator values of the higher plants in the Hungarian flora. Acta Bot. Hung. 39, 97-181.

Csorba, P., Szabó, Sz., 2009. Degree of human transformation of landscapes: a case study from Hungary. Hung. Geogr. Bulletin 58 (2), 91-99. http://www.mtafki.hu/ konyvtar/kiadv/HunGeoBull2009/HunGeoBull_2009_2_91-99.pdf.

Csorba, P., 2005. Landscape ecological fragmentation of the small landscape unit (microregions) of Hungary based on the settlement network and traffic infrastructure. Hung. Geogr. Bulletin 54, 243-263. http://www.mtafki.hu/konyvtar/kiadv/ FE2005/FE20053-4_243-263.pdf.

Czúcz, B., Molnár, Zs., Horváth, F., Botta-Dukát, Z., 2008. The natural capital index of Hungary. Acta Bot. Hung. 50 (Suppl. 8), 161-177. http://dx.doi.org/10.1556/ABot. 50.2008.

Czúcz, B., Molnár, Zs., Horváth, F., Nagy, G., Botta-Dukát, Z., Török, K., 2012. Using the natural capital index framework as a scalable aggregation methodology for regional biodiversity indicators. J. Nat. Conserv. 20, 144-152. http://dx.doi.org/10.1016/j. jnc.2011.11.002.

Deák, B., Valkó, O., Török, P., Kelemen, A., Tóth, K., Miglécz, T., Tóthmeresz, B., 2015. Reed cut habitat diversity and productivity in wetlands. Ecol. Complex 22, 121-125. http://dx.doi.org/10.1016/j.ecocom.2015.02.010.

EEA, ETC-TE, 2002. CORINE Land Cover Update CLC 2000 Project. Technical Guidelines. Final Version. EEA, Denmark. Available at: http://land.copernicus.eu/user-corner/ 
technical-library/techrep89.pdf (accessed 2016 December).

EEA, 2006. The Thematic Accuracy of CORINE Land Cover 2000. Assessment Using LUCAS (Land Use/cover Area Frame Statistical Survey). EEA, Coppenhagen, Denmark. Available at: http://land.copernicus.eu/user-corner/technical-library/ technical_report_7_2006.pdf (accessed 2016 December).

Forman, R.T.T., 1995. Land Mosaics - The Ecology of Landscape and Regions. Cambridge University Press, Cambridge, pp. 632.

Frank, S., Fürst, C., Koschke, L., Makeschin, F., 2012. A contribution towards a transfer of the ecosystem service concept to landscape planning using landscape metrics. Ecol. Indic. 21, 30-38. http://dx.doi.org/10.1016/j.ecolind.2011.04.027.

Frondoni, R., Mollo, B., Capotorti, C., 2011. A landscape analysis of land cover change in the Municipality of Rome (Italy): spatio-temporal characteristics and ecological implications of land cover transitions from 1954 to 2001. Landsc. Urban Plan. 100, 117-128. http://dx.doi.org/10.1016/j.landurbplan.2010.12.002.

Fu, B.J., Hu, C.-X., Che, L.D., Honnya, O., Gullink, H., 2006. Evaluating change in agricultural landscape pattern between 1980 and 2000 in the Loess hilly region of Ansai County. China. Agr. Ecosyst. Environ. 114, 387-396. http://dx.doi.org/10.1016/j. agee.2005.11.012.

Gimona, A., Messager, P., Occhi, M., 2009. CORINE-based landscape indices weakly correlate with plant species richness in a northern European landscape transect. Landsc. Ecol. 24, 53-64. http://dx.doi.org/10.1007/s10980-008-9279-7.

Herzog, F., Lausch, A., Müller, E., Thulke, H.H., Steinhardt, U., Lehmann, S., 2001. Landscape metrics for assessment of landscape destruction and rehabilitation. Environ. Manage. 27 (1), 91-107. http://dx.doi.org/10.1007/s002670010136.

Horváth, F., Molnár, Zs., Bölöni, J., Pataki, Zs., Polgár, L., Révész, A., Krasser, D., Illyés, E., 2008. Fact sheet of the MÉTA database 1.2. Acta Bot. Hung. 50 (Suppl. 2), 11-34. http://dx.doi.org/10.1556/ABot.50.2008.

Jalas, J., 1955. Hemerobe und hemechore Pflanzenarten Ein terminologischer Reformversuch. Acta Fauna Flora Fenn. 72, 1-15.

Kerényi, A., Szabó, G., 2007. Human impact on topography and landscape pattern in the Upper Tisza region, NE-Hungary. Geogr. Fis. Din. Quat. 30, 193-196. http://www. glaciologia.it/wp-content/uploads/FullText/full_text_30_2/07_Ker\%C3\%A9nyi_193 196.pdf.

Landscapes and Landforms of Hungary. In: Lóczy, D. (Ed.), Springer, Leverkusen, pp. 294.

Lang, S., Tiede, D., 2003. vLATE Extension für ArcGIS - vektorbasiertes Tool zur quantitativen Landschaftsstrukturanalyse ESRI Anwenderkonferenz 2003 Innsbruck CDROM.

Lausch, A., Herzog, F., 2002. Applicability of landscape metrics for the monitoring of landscape change: issues of scale, resolution and interpretability. Ecol. Indic. 2, 3-15. http://dx.doi.org/10.1016/S1470-160X(02)00053-5.

Lausch, A., Blaschke, T., Haase, D., Herzog, F., Syrbe, R.U., Tischendorf, T., Walz, U., 2015. Understanding and quantifying landscape structure - a review on relevant process characteristics, data models and landscape metrics. Ecol. Model. 295, 35-41. http://dx.doi.org/10.1016/j.ecolmodel.2014.08.018.

Machado, A., 2004. An index of naturalness. J. Nat. Conserv. 12, 95-110. http://dx.doi. org/10.1016/j.jnc.2003.12.002.

Mander, Ü., Müller, F., Wrbka, T., 2005. Functional and structural landscape indicators: upscaling and downscaling problems. Ecol. Indic. 5, 267-272. http://dx.doi.org/10. 1016/j.ecolind.2005.04.001.

Mezősi, G., 2011. Environmental Capabilities, Hazards and Conflicts in Hungary. Univ Szeged, Szeged, pp. 214

Molnár, Zs., Bartha, S., Seregélyes, T., Illyés, E., Botta-Dukát, Z., Tímár, G., Horváth, F., Révész, A., Kun, A., Bölöni, J., Biró, M., Bodonczi, L., Deák, J.A., Fogarasi, P., Horváth, A., Isépy, I., Karas, L., Kecskés, F., Molnár, Cs., Ortmann-né Ajkai, Cs., Rév Sz, A., 2007. A grid-based, satellite-image supported, multi-attributed vegetation mapping method (MÉTA). Folia Geobot. 42, 225-247. http://dx.doi.org/10.1007/ BF02806465.

Moser, D., Zechmeister, H.G., Plutzar, C., Sauberer, N., Wrbka, T., Grabherr, G., 2002. Landscape patch shape complexity as an effective measure for plant species richness in rural landscapes. Landsc. Ecol. 17, 657-669. http://dx.doi.org/10.1023/ A:1021513729205.

OECD, 2001. Environmental indicators: towards sustainable development. In: Organisation for Economic Co-operation and Development. Paris. . Available at: http://www.oecd.org/site/worldforum/33703867.pdf (Accessed 2016 December).

Rüdisser, J., Tasser, E., Tappeiner, U., 2012. Biodiversität in Österreich -ihre erfassung und der einfluss der landnutzung. In beiträge zum 24. In: AGIT-Symposium Salzburg. Angewandte Geoinformatik Salzburg: Wichmann, Berlin/Offenbach. . Available at: http://gispoint.de/fileadmin/user_upload/paper_gis_open/537520072.pdf (Accessed 2016 December)

Renetzeder, C., Schindler, S., Prinz, M.A., Muücher, C.A., Wrbka, T., 2010. Can we measure ecological sustainability? Landscape pattern as an indicator for naturalness and land use intensity at regional, national and European level. Ecol. Indic. 10, 39-48. http://dx.doi.org/10.1016/j.ecolind.2009.03.017.

Schindler, S., Poirazidis, K., Wrbka, T., 2008. Towards a core set of landscape metrics for biodiversity assessments: a case study from Dadia National Park. Greece Ecol. Indic. 8, 502-514. http://dx.doi.org/10.1016/j.ecolind.2007.06.001.

Sokal, R.R., Rohlf, F.J., 1969. Introduction to Biostatistics, 2nd edition. W.H. Freeman and Company, New York, pp. 363.

Sukopp, H., 1976. Dynamik und Konstanz in der Flora der Bundesrepublik Deutschland. Schr.-R. f. Vegetationskunde 9-27.

Szabó, Sz., Szilassi, P., Csorba, P., 2012. Tools for landscape ecological planning-scale, and aggregation sensitivity of the contagion type landscape metric indices. Carpath. J. Earth Environ. 7, 127-136. http://www.ubm.ro/sites/CJEES/viewTopic.php? topicId $=249$.

Szabó, Sz., Bertalan, L., Kerekes, A., Novak, T.J., 2013. Possibilities of land use change analysis in a mountainous rural area: a methodological approach. Int. J. Geogr. Inf. Sci. 30, 708-726. http://dx.doi.org/10.1080/13658816.2015.1092546.

Szilassi, P., Jordan, G., van Rompaey, A., Csillag, G., 2006. Impacts of historical land use changes on erosion and agricultural soil properties in the Kali Basin at Lake Balaton. Hungary Catena 68, 96-108. http://dx.doi.org/10.1016/j.catena.2006.03.010.

Tasser, E., Sternbach, E., Tappeiner, U., 2008. Biodiversity indicators for sustainability monitoring at municipality level: an example of implementation in an alpine region. Ecol. Indic. 8, 204-223. http://dx.doi.org/10.1016/j.ecolind.2007.01.005.

Tischendorf, L., 2001. Can landscape indices predict ecological processes consistently? Landsc. Ecol. 16, 235-254. http://dx.doi.org/10.1023/A:1011112719782.

Turner, M.G., 1990. Spatial and temporal analysis of landscape patterns. Landsc. Ecol. 4, 21-30. http://dx.doi.org/10.1007/BF02573948.

Uuemaa, E., Mander, Ü., Marja, R., 2013. Trends in the use of landscape spatial metrics as landscape indicators: a review. Ecol. Indic. 28, 100-106. http://dx.doi.org/10.1016/ j.ecolind.2012.07.018.

Venturelli, R.C., Galli, A., 2006. Integrated indicators in environmental planning: methodological considerations and applications. Ecol. Indic. 6, 228-237. http://dx.doi. org/10.1016/j.ecolind.2005.08.023.

Walz, U., Stein, C., 2014. Indicators of hemeroby for the monitoring of landscapes in Germany. J. Nat. Conserv. 22, 279-289. http://dx.doi.org/10.1016/j.jnc.2014.01. 007.

Walz, U., Syrbe, R.U., 2013. Linking landscape structure and biodiversity. Ecol. Indic. 31, 1-5. http://dx.doi.org/10.1016/j.ecolind.2013.01.032.

Walz, U., 2008. Monitoring of landscape change and functions in Saxony (Eastern Germany) - methods and indicators. Ecol. Indic. 8, 807-817. http://dx.doi.org/10. 1016/j.ecolind.2007.09.006.

Walz, U., 2011. Landscape structure, landscape metrics and biodiversity living. Rev. Landsc. Res. 5 (3), 35. http://lrlr.landscapeonline.de/Articles/lrlr-2011-3/ download/lrlr-2011-3Color.pdf.

Winter, H.S., Fischer, A., 2010. Relative quantitative reference approach for naturalness assessments of forests. Forest Ecol. Manag. 259, 1624-1632. http://dx.doi.org/10. 1016/j.foreco.2010.01.040.

Wrbka, T., Erb, K.H., Schulz, N.B., Peterseil, J., Hahn, C., Haberl, H., 2004. Linking pattern and process in cultural landscapes. An empirical study based on spatially explicit indicators. Land Use Policy 21, 289-306. http://dx.doi.org/10.1016/j. landusepol.2003.10.012.

Zebisch, F., Wechsung, H., Kenneweg, M., 2004. Landscape response functions for biodiversity-assessing the impact of land-use changes at the county level. Landsc. Urban Plan. 67, 157-172. http://dx.doi.org/10.1016/S0169-2046(03)00036-7.

Zhang, Z., Van Coillie, F., De Clercqc, E.M., Oua, X., De Wulf, R., 2013. Mountain vegetation change quantification using surface landscape metrics in Lancang watershed. China Ecol. Indic. 31, 49-58. http://dx.doi.org/10.1016/j.ecolind.2012.11. 013.

ten Brink, B., van Hinsberg, A., de Heer, M., van der Hoek, D.J.C., de Knegt, B., Knol, O.M., Ligtvoet, W., Reijnen, M.J.S.M., Rosenboom, R., 2002. Technisch Ontwerp Natuurwaarde 1.0 En Toepassing in Natuurverkenning 2 (Technical Design Natural Capital Index Framework and Implementation for the Nature Outlook 2). RIVM Rapport 408657007. pp. 189. http://pblweb10. prolocation.net/sites/default/files/ cms/publicaties/408657007.pdf.

ten Brink, 2001. Biodiversity Indicators for the OECD Environmental Outlook and Strategy?A Feasibility Study. RIVM Report 402001014. Globio Report Series No 25. Available at: http://www.rivm.nl/bibliotheek/rapporten/402001014.pdf (Accessed 2016 December).

ten Brink, 2007. The natural capital index framework (NCI). In: Contribution to Beyond GDP Virtual Indicator Expo. Brussels, 19-20 November 2007. pp. 19-20. 